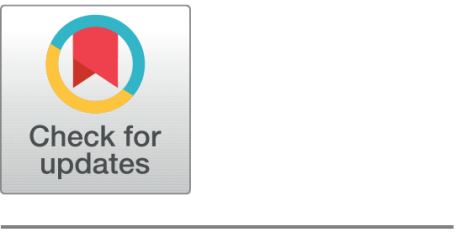

OPEN ACCESS

Received: 07.07.2020

Accepted: 28.08 .2020

Published: 06.10 .2020

Editor: Dr. Natarajan Gajendran

Citation: Islam MA, Sheikh A, Waterman C, Hosenuzzaman M (2020) Morphology, pod yield and nutritional quality of two cultivars of Moringa (Moringa oleifera) in Bangladesh. Indian Journal of Science and Technology 13(37): 3893-3903. https://doi.org/ 10.17485/IJST/v13i37.1083

* Corresponding author.

ashrafulmi@bau.edu.bd

Funding: None

Competing Interests: None

Copyright: (c) 2020 Islam et al. This is an open access article distributed under the terms of the Creative Commons Attribution License, which permits unrestricted use, distribution, and reproduction in any medium, provided the original author and source are credited.

Published By Indian Society for Education and Environment (iSee)

ISSN

Print: 0974-6846

Electronic: 0974-5645

\section{Morphology, pod yield and nutritional quality of two cultivars of Moringa (Moringa oleifera) in Bangladesh}

\author{
M Ashraful Islam ${ }^{1 *}$, Alamin Sheikh ${ }^{1}$, Carrie Waterman ${ }^{2}$, Md Hosenuzzaman $^{3}$ \\ 1 Department of Horticulture, Bangladesh Agricultural University, Mymensingh, 2202, \\ Bangladesh \\ 2 Department of Nutrition, University of California, Davis, USA \\ 3 Department of Soil Science, Bangladesh Agricultural University, Mymensingh, 2202, \\ Bangladesh
}

\section{Abstract}

Background/Objectives: Moringa (Moringa oleifera) is a multi-purpose tree with valuable nutritional density found in the leaves and pods. Both seasonal and year-round cultivars are available and consumed in Bangladesh. This study evaluated the qualitative and quantitative morphological characteristics and nutritional content in leaves and pods of moringa cultivars from two major ecological locations in Bangladesh. Methodology: The selected local varieties used were seasonal production (SP: V1) and year-round production (YP: V2) cultivars from the two ecological regions Chapai Nawabganj $\left(L_{1}\right)$ and Pabna $\left(\mathrm{L}_{2}\right)$. Findings: Flowering and fruiting occurred once per year in seasonal cultivar (SP) and three times per year in year-round cultivar (YP). Flowers are zygomorphic; and tripinnate and pinnately compound leaves in both cultivars. The average yield of pods over two years of production for V1 was 45-62 kg/year/plant and 27-38 kg/plant/year for V2. Leaves contained more than two times higher protein (29-36\%) compared to pods (11-15\%). Similarly, nutrients including calcium and iron were significantly higher in leaves (2314-3487 ppm and 276-418 ppm, respectively) than pods (2017-2032 ppm and 61-68 ppm, respectively). There were no significant differences in potassium content of both cultivars in both location, but pod contained more than four times higher phosphorus (1.5-1.7\%) than leaves $(0.34-0.38 \%)$. The highest amounts of magnesium (1768-1861 ppm) and sodium (496-535 ppm) were found in pods. Applications: Cultivar and plant part (e.g leaves) can be considered when promoting and utilizing moringa micronutrient for nutritional security. It demands for policies and development actions for production and intensification of moringa in dry parts of the country.

Keywords: Moringa; cultivars; leaves; pods; morphology; nutritional security 


\section{Introduction}

Moringa (Moringa oleifera) is a multipurpose tree with horticultural, medicinal, nutritional, and industrial uses ${ }^{(1,2)}$. It is one of thirteen species in the monogenic family Moringaceae. It is also called drumstick, Benzolive, Horseradish, Kelor, Marango, Mulangay, Sajan among several other local and regional names ${ }^{(1,3)}$. Emongor et al. ${ }^{(4)}$ reported that height of moringa can be up to 9-15 meter. Different parts of the moringa plant are commonly recommended for the treatment of skin diseases, respiratory illnesses, ear and dental infections, hypertension, diabetes, cancer and cardiovascular disease ${ }^{(3,5,6)}$. While emerging in vitro and in vivo data has supported many of the potential health effects along with a few small clinical studies and more rigorous clinical trial are needed to evaluate the efficacy in humans ${ }^{(7)}$. In many developing countries, the leaves are used to combat malnutrition and the seeds for water purification ${ }^{(3,5,6,8)}$. Leaves have been used to for infants and nursing mothers to increase milk production and weight gain in nursing infants ${ }^{(9,10)}$. Overall, Moringa has a great potentiality regarding nutrition and should be further explored for its use in health and disease management. The oil from the seeds can be used as cooking oil, biodiesel and for making soaps and cosmetics ${ }^{(11-18)}$. Overall, the moringa tree has great potential to improve nutrition, boost food security and foster rural development ${ }^{(19)}$.

The ability of moringa to address nutritional deficiencies is based on the abundance of vitamins, minerals and protein found in the leaves and pods. These include vital nutrients such as beta-carotene, iron, zinc, vitamin C and all essential amino acids ${ }^{(20)}$. The plant also contains other bioactive and anti-inflammatory compounds like phenolics and isothiocyanates, while being relatively low in antinutrients ${ }^{(21-25)}$. A high degree of interest has grown on utilizing the nutritional properties of moringa in several countries where it is not native ${ }^{(13,26)}$. Nutrient fortification in food through supplementation of moringa leaves powder in bread increased the nutrient content like calcium, magnesium and beta-carotene ${ }^{(27)}$. School children that consumed moringa- snack foods fortified with $3 \mathrm{~g}$ of moringa exhibited increased hemoglobin (an indicator for reduced anemia), vitamin $\mathrm{A}$ and folic acid levels ${ }^{(28)}$. Some information has been published on the nutritional profile of moringa leaves, flowers, and pods from different varieties and locations ${ }^{(11,29-31)}$. However, there is limited data on such characteristics of moringa cultivars from Bangladesh.

People of Bangladesh are used to consuming both leaves and pods depending on their regional and habitual practices. However, many are unaware of the nutritional and potential health benefits of moringa and differences of these among the different edible parts. In Bangladesh, major moringa growing areas are Chapai Nawabganj, Rajshahi, Pabna, Jashore, Kushtia, Rangpur, Natore, Bogra and other districts profusely growing in the homestead and roadside areas. It grows widely in the climate vulnerable areas like drought and saline belt areas as well but does not do well in areas with water-logged soils. Diversified cultivars of moringa are available in Bangladesh and locally known as sajna, lajna, aikhonjon etc. Flowering and fruiting times are noticeable among the year round and seasonal cultivars. There has been recent interest to organize standardized cultivation for monitoring, standardizing for improving the nutritional security and processing industry of leaves.

Moringa is very rich nutrient crops considered as minor in Bangladesh and still no comparison yield and nutritional data available of different consumable parts of moringa in Bangladesh. This study has given the clear picture of rich sources of different micronutrient from either leaves or pods. Seasonal and year-round cultivars from two major growing moringa locations have been examined for their qualitative and quantitative morphological traits and the nutritional profile of the pods and leaves, the parts most commonly consumed by Bangladeshi people.

\section{Materials and methods}

\subsection{Study area and design of the experiment}

The study was conducted from January 2016 through December 2017. Two major moringa growing regions in Bangladesh were selected namely, Chapai Nawabganj (Sadar Upazila: $\mathrm{L}_{1}$ ) and Pabna (Iswardi upazila: $\mathrm{L}_{2}$ ). Both locations are located in the North-Western parts belongs to Rajshahi divisions of Bangladesh ( Figure 1). Chapai Nawabganj is situated between the latitude $24^{\prime} 22$ to $24^{\prime} 57$ and longitude $87^{\prime} 23$ to $88^{\prime} 23$. Iswardi, in the Pabna district, is located at $24^{\prime} 22$ and $89^{\prime} 14$. Chapai Nawabganj and Pabna are close to the large city Rajshahi and the climate of both districts is very close which represent High Ganges River Floodplain (AEZ11) and Low Ganges River Floodplain (AEZ 12), respectively. Two cultivars namely, $\mathrm{V}_{1}$ : seasonal production (SP) and $\mathrm{V}_{2}$ : year-round production (YP) were selected for each location; and each cultivar consists of four plants from each region. Each plant considered as one replication. Total numbers of plants were $16(2 \times 2 \times 4)$. 

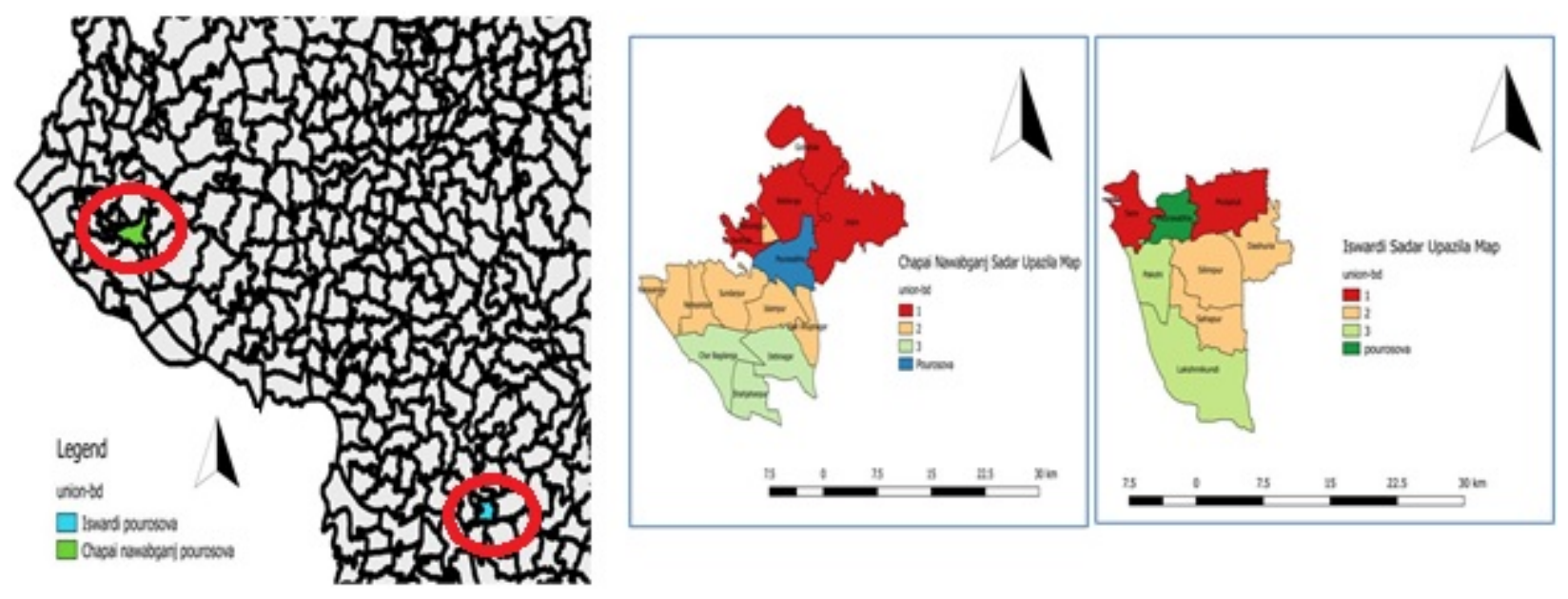

Fig 1. Study areas (circled red color-Iswardi upazilla under Pabna and Sadar upazilla under Chapai Nawabganj districts) indicated in the map (partly) of Bangladesh (left side). Two districts are given in the right side where Pourosova /sadar upazilla are indicated.

Plant morphology and yield data of the two cultivars were collected in both regions. Leaves and pods were collected from the selected areas and their nutrition quality were analyzed in the laboratory of Horticulture Department and Humboldt Soil Science Laboratory of Bangladesh Agricultural University (BAU), Mymensingh, Bangladesh. Both locations marked with monsoon, high temperature, considerable humidity and moderate rainfall. Details of average temperature, rainfall and relative humidity are shown in Figure 2.

\subsection{Morphological study}

Moringa farmers were interviewed to know the morphological characteristics of leaves and pods including leaves arrangement, number of secondary leaves, and flowers and pods characteristics were recorded. Pod length $(\mathrm{cm})$ including the fresh weight of pod $(\mathrm{g})$, diameter of pod $(\mathrm{cm})$ were measured. Subsequently, pods were splitted and documented the number of seeds per pod and 100 seed weight $(\mathrm{g})$.

\subsection{Nutritional composition analysis}

Nutritional analysis was conducted at the Humboldt Soil Science Laboratory, BAU. Leaves and pods were oven dried at $65^{\circ} \mathrm{C}$ until a constant mass was reached and calculated the moisture percentage and dry matter percentage. Nutrients content like protein, phosphorous $(\mathrm{P})$, potassium $(\mathrm{K})$, calcium $(\mathrm{Ca})$, magnesium $(\mathrm{Mg})$, sodium $(\mathrm{Na})$ and iron $(\mathrm{Fe})$ were determined and their details protocol mentioned below.

Nitrogen content of leaves and pods was determined following the Kjeldahl method ${ }^{(32)}$. The total protein content was calculated by multiplying the nitrogen content with a conversion factor (6.25).

Leaves and pods were digested using di-acid mixture (conc. $\mathrm{HNO}_{3}: \mathrm{HClO}_{4}=2: 1$ ) as described by Singh et al. ${ }^{(33)}$. In this method, $2 \mathrm{~g}$ of finely grinded samples were taken and digested. The solution was used for the determination of mineral contents ( $\mathrm{Ca}, \mathrm{Mg}$, and $\mathrm{Fe}$ ) compared to a standard curve for each element using atomic absorption spectrometer (AAS) 969 UNICAM. Sample blank was run in all the analysis ${ }^{(34)}$.

$\mathrm{P}$ content in the digest was determined by developing phosphomolybdate blue complex with stannous chloride $\left(\mathrm{SnCl}_{2} \cdot 2 \mathrm{H}_{2} \mathrm{O}\right)$ and measuring the absorbance of color with the help of a spectrophotometer (Model- T60, PG Instruments, $\mathrm{UK})$ at $660 \mathrm{~nm}$ wavelength against standard ${ }^{(35)}$.

$\mathrm{K}$ and $\mathrm{Na}$ contents in the digest were determined using flame emission spectrophotometer. The intensity of light emitted by potassium and sodium at 767 and $589 \mathrm{~nm}$, respectively was directly proportional to the concentration of $\mathrm{K}$ and Na present in the sample. The percent emission for the elements was recorded and the $\mathrm{K}$ and $\mathrm{Na}$ concentration was determined against standards ${ }^{(36)}$. 

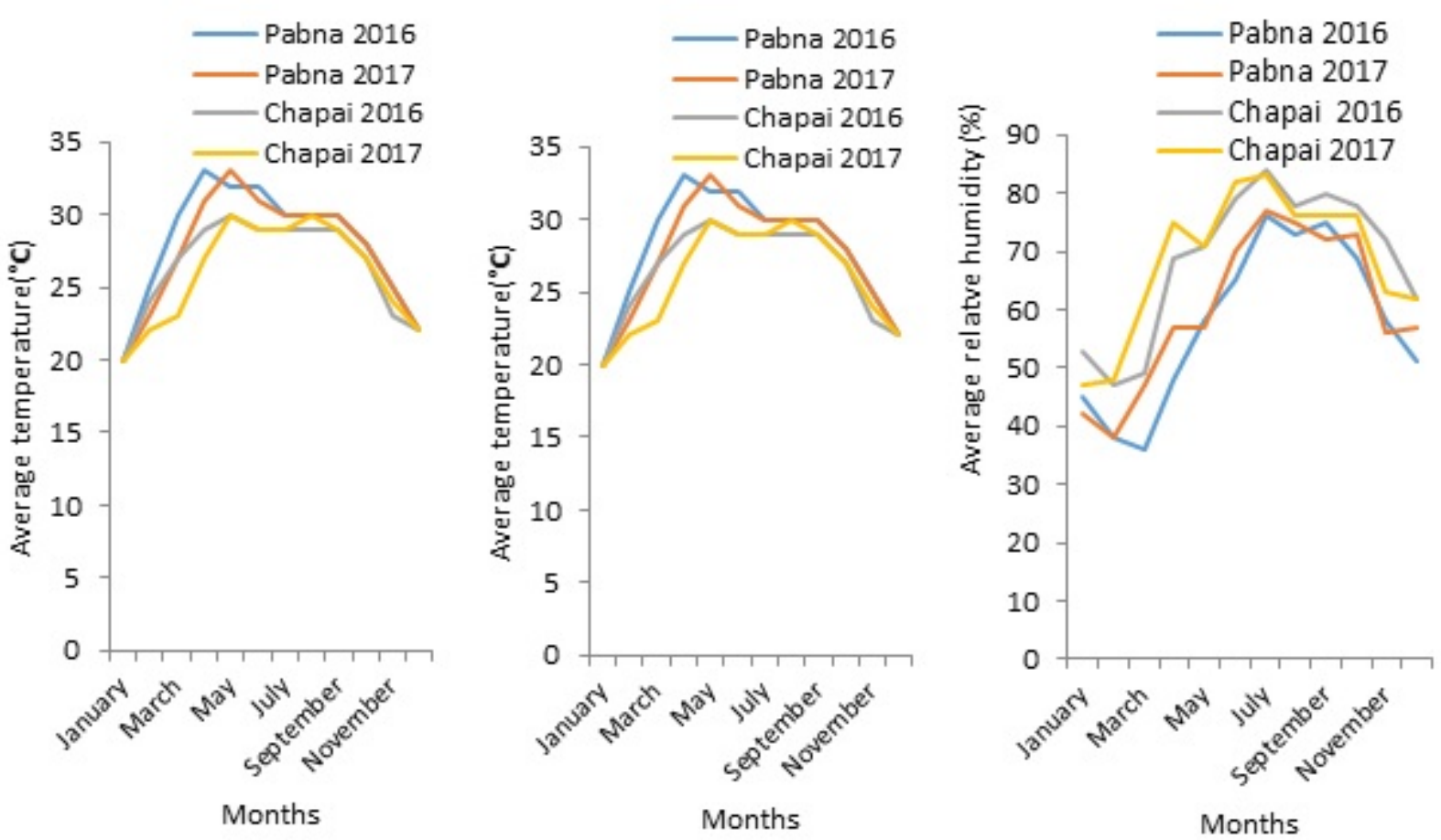

Fig 2. Meteorological data of the year 2016 and 2017 for the study areas, Chapai Nawabganj and Pabna districts. Source: Bangladesh Meteorological Department.

\subsection{Statistical analysis}

Data on different parameters were analyzed using Minitab version 17 (Minitab Inc., State College, PA, USA) by analysis of variance (General Linear Model procedure) and Tukey's pair wise comparison test $(\mathrm{p}<0.05)$.

\section{Results and discussion}

Two cultivars from two major growing regions of moringa were analyzed for morphological characteristics, yield comparisons of two subsequent years of harvest; and nutritional analysis (protein, $\mathrm{P}, \mathrm{Ca}, \mathrm{Na}, \mathrm{Mg}$ and $\mathrm{Fe}$ ) of both leaves and pods.

\subsection{Qualitative and quantitative morphological study of moringa cultivars}

Botanical observation was studied of two cultivars of moringa ( $\mathrm{V}_{1}$ : seasonal production-SP and $\mathrm{V}_{2}$ : year-round production- $\left.\mathrm{YP}\right)$ from two locations under the district of Chapai Nawabganj (Sadar upazila: $L_{1}$ ) and Pabna (Iswardi upazila: $L_{2}$ ) districts.

The leaves are alternate and commonly pinnate compound leaves (imparipinnate) which are found tri-pinnate in both cultivars ( Figure 3). Average length of main rachis was significantly higher and the range between $53-59 \mathrm{~cm}$ in the seasonal compared to year-round cultivar $(18-26 \mathrm{~cm})$ ( Table 1 ). Rachis length was found to be similar among cultivar and was not influenced by different location. The number of secondary rachis per main rachis were significantly influenced by both cultivars and ecological difference. A higher number of secondary rachis in the main rachis (12-15) were observed in SP cultivar compared to YP (7-8) cultivar ( Table 1). Ultimately, this difference has the influence on biomass production of leaves and the fruit yield of moringa. In both cultivars, the leaflets are dark green or light green; and most of the cases dark green in the upper surface and light green in the lower surface, apex is rounded short-pointed as well as oblique sided as base.

In both cultivars the zygomorphic flowers had a white to cream color ( Figure 3). The flower contained sepals (5), petals (10), and slender stamens ( 5 with anthers and 5 without anthers). Petals were longer and unequal (Figure 3). Flowering, as well as fruiting, occurs once in the seasonal cultivar and three times in the year-round cultivar where flowers or fruits are available the 
whole year except January and February. On the other hand, the seasonal cultivar production period is from the end of January until April. Details of further differentiation between the two cultivars are discussed in Table 2.

Table 1. Interaction effect of diameter of plant and yield per plant of two moringa varieties of two different locations

\begin{tabular}{llllll}
\hline location & Cultivar & Leaf length $(\mathrm{cm})$ & No of secondary rachis & Fruit length(cm) & Number of seeds/pod \\
\hline \multirow{2}{*}{ ChapaiNawabgang (L1) } & SP & $59.29 \pm 3.00 \mathrm{a}$ & $11.762 \pm 0.40 \mathrm{ab}$ & $49.08 \pm 0.36 \mathrm{a}$ & $17.17 \pm 0.68 \mathrm{a}$ \\
& YP & $25.89 \pm 1.97 \mathrm{~b}$ & $8.28 \pm 0.12 \mathrm{bc}$ & $31.98 \pm 0.94 \mathrm{~b}$ & $13.65 \pm 0.62 \mathrm{~b}$ \\
\hline \multirow{2}{*}{ Pabna (L2) } & SP & $53.37 \pm 0.81 \mathrm{a}$ & $14.59 \pm 2.22 \mathrm{a}$ & $47.78 \pm 2.08 \mathrm{a}$ & $16.99 \pm 0.68 \mathrm{a}$ \\
& YP & $17.82 \pm 1.13 \mathrm{~b}$ & $6.500 \pm 0.39 \mathrm{c}$ & $37.98 \pm 2.83 \mathrm{~b}$ & $14.30 \pm 0.87 \mathrm{ab}$ \\
\hline
\end{tabular}

Mean \pm SE (standard error) followed by non-similar letters are significantly different at $\mathrm{p}<0.05$ according to Tukey's test. Here, SP: seasonal production cultivar and YP: Year-round production cultivar.
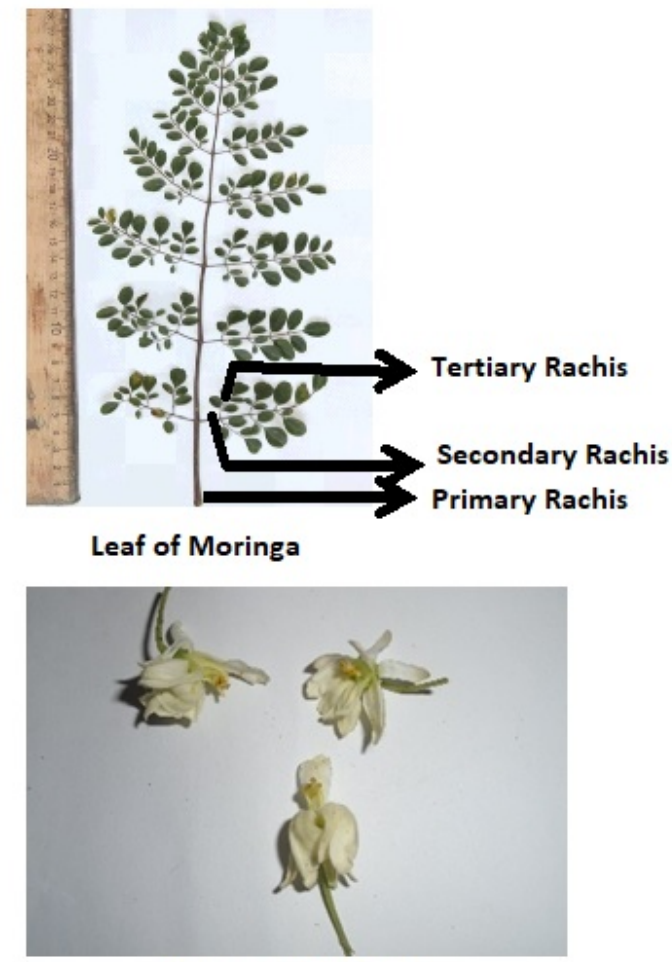

Flowers of Moringa

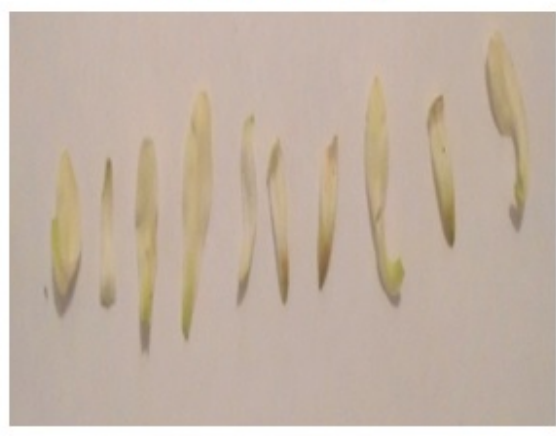

Petals of Moringa flowers

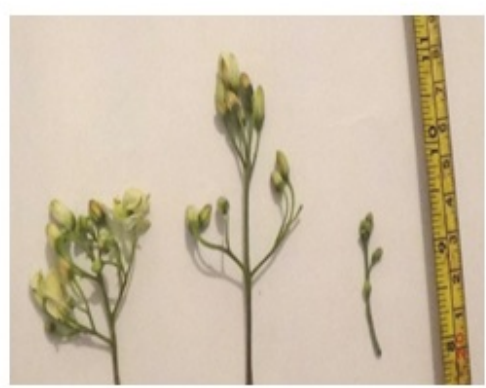

Different stages of inflorescence

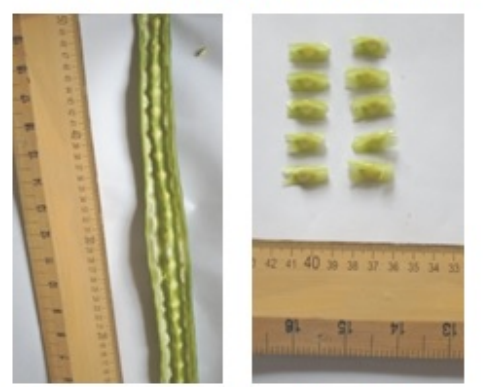

Pod disesection and seeds of Moringa

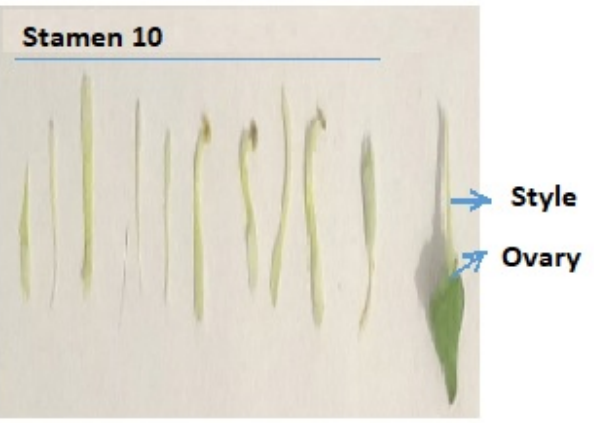

Stamens (5 with anther and 5 without anther) and ovary of Moringa

Fig 3. Different parts of moringa plants 
Table 2. Comparative information on seasonal and year-round cultivars at a glimpse.

\begin{tabular}{|c|c|c|}
\hline Parameter & Seasonal production (SP) cultivar & Year-round production (YP) cultivar \\
\hline Plant height & Plants are generally longer in size & $\begin{array}{l}\text { Plants are generally shorter in size compared to } \\
\text { seasonal production cultivar. }\end{array}$ \\
\hline Stem/Base & $\begin{array}{l}\text { Main stem diameter is comparatively bigger than the year } \\
\text { round cultivar. }\end{array}$ & $\begin{array}{l}\text { Main stem diameter is comparatively smaller } \\
\text { than the year round cultivar. }\end{array}$ \\
\hline Leaves & $\begin{array}{l}\text { Leaf length and leaflets of seasonal cultivar are bigger } \\
\text { than year-round cultivar }\end{array}$ & $\begin{array}{l}\text { Leaf length and leaflets are shorter than seasonal } \\
\text { production cultivar. }\end{array}$ \\
\hline Flower & $\begin{array}{l}\text { In both cultivars: flowers are white or creamy type. Sepal: } \\
\text { without anthers. }\end{array}$ & Petal: 5, Stamen (10) where 5 with anthers and 5 \\
\hline $\begin{array}{l}\text { Flowering and harvest- } \\
\text { ing of fruits/pods }\end{array}$ & $\begin{array}{l}\text { Flowering time: Last week of January to March } \\
\text { Fruiting and harvesting time: March to April }\end{array}$ & $\begin{array}{l}\text { Flowering and fruiting three times per year } \\
\text { 1st -Flowering time: Last week of February to last } \\
\text { week of March } \\
\text { Fruiting and harvesting time: Mid-March to June } \\
\text { 2nd - Flowering time: June } \\
\text { Fruiting and harvesting time: Mid July to Septem- } \\
\text { ber } \\
\text { 3rd - Flowering time: October } \\
\text { Fruiting and harvesting time: November to } \\
\text { December }\end{array}$ \\
\hline Fruit & Fruit size is longer compared to year-round cultivar. & Fruit size is shorter compared to seasonal cultivar. \\
\hline Number of seed per pod & $\begin{array}{l}\text { Number of seeds per pod higher than year-round } \\
\text { cultivar. }\end{array}$ & $\begin{array}{l}\text { Number of seeds per pod lower than seasonal } \\
\text { cultivar. }\end{array}$ \\
\hline
\end{tabular}

The green pod is beaked (apex pointed and tapering at the base), pendulous, linear and with longitudinal ridges. Both seasonal and year-round cultivars fruit length and pod yield, seeds per pod were significantly different ( Table 1). The highest length of pod $(49.08 \mathrm{~cm})$ was found in seasonal cultivar and the lowest was $31.98 \mathrm{~cm}$ in year-round. In both locations have the significant variations of fruit length among the cultivars. The range of the fruit/pod length of SP $(48-49 \mathrm{~cm})$ was higher than the range found with YP $(32-38 \mathrm{~cm})$ considering the both ecological zones. Pod length of different ecological zones of Saudi Arabia found variation ${ }^{(37)}$. Pod length result is consistence with the production of moringa considering locations and cultivars of this study. It has been observed that pod formation is less time consuming in the year round and a bit more time need in case of seasonal cultivar. After longitudinal section of green/immature pod, seeds were found inside the pod. Seeds embedded in pith, parietal placentation, pale green seeds, whereas matured seeds become ivory-white to brownish with whitish papery and deciduous wings on the angles. It can be noticed that over matured seeds caused unacceptability of pod for human consumption. The highest number of seeds per pod were found 18 in the seasonal cultivars of Chapai Nawabganj district and the lowest number of seeds per pod is 14 found in year-round cultivars of Pabna district ( Table 1). Average ranging of seeds per pod is 14-18 whereas the seeds per pod is higher compared to the study of Osman and Abohassan ${ }^{(37)}$. In our study, the significant difference of seeds per pod was found among the cultivars but there is no significant difference was found in same cultivars of the two locations. Number of seeds per pod and pod length were found in the different accessions of moringa ${ }^{(38)}$. Overall, the fruit length and number of seeds per pod was higher in the SP cultivar might be the reason for higher yield compared to YP cultivar ( Tables 1 and 3).

Table 3. Quantitative morphological features of moringa fruit

\begin{tabular}{lllllll}
\hline location & Cultivar & $\begin{array}{l}\text { fresh wt. /pod } \\
(\mathrm{gm})\end{array}$ & $\begin{array}{l}\text { average diameter } \\
\text { pod }(\mathrm{cm})\end{array}$ & $\begin{array}{l}\text { 100 seed weight } \\
(\mathrm{gm})\end{array}$ & $\begin{array}{l}\text { Moisture (\%) of } \\
\text { leaves }\end{array}$ & $\begin{array}{l}\text { Dry matter (\%) of } \\
\text { leaves }\end{array}$ \\
\hline Chapai & SP & $18.68 \pm 1.76 \mathrm{ab}$ & $0.69 \pm 0.034 \mathrm{ab}$ & $21.25 \pm 1.49 \mathrm{a}$ & $68.82 \pm 1.38 \mathrm{a}$ & $31.18 \pm 1.38 \mathrm{a}$ \\
Nawabgang (L1) & YP & $15.84 \pm 1.45 \mathrm{ab}$ & $1.06 \pm 0.17 \mathrm{a}$ & $18.208 \pm 0.91 \mathrm{a}$ & $71.10 \pm 1.11 \mathrm{a}$ & $28.90 \pm 1.11 \mathrm{a}$ \\
\hline Pabna (L2) & SP & $21.04 \pm 1.32 \mathrm{a}$ & $0.75 \pm 0.03 \mathrm{ab}$ & $17.63 \pm 0.58 \mathrm{a}$ & $73.60 \pm 3.09 \mathrm{a}$ & $26.40 \pm 3.09 \mathrm{a}$ \\
& YP & $12.83 \pm 1.11 \mathrm{~b}$ & $0.60 \pm 0.06 \mathrm{~b}$ & $8.54 \pm 0.62 \mathrm{~b}$ & $73.450 \pm 0.91 \mathrm{a}$ & $26.550 \pm 0.91 \mathrm{a}$ \\
\hline
\end{tabular}

Mean \pm SE (standard error) followed by non-similar letters are significantly different at $\mathrm{p}<0.05$ according to Tukey's test. Here, SP: seasonal production cultivar and YP: Year-round production cultivar. 


\subsection{Pod yield of moringa}

Immature pod weight was found significantly different considering the cultivars and ecological zones. In Pabna, pod weight of seasonal cultivar (SP) was found higher (21 g) compared to year round (YP) cultivar (13 g) ( Table 3 ). Although, no significant variations among the cultivars was found in Chapai nawabgang $\left(\mathrm{L}_{1}\right)$. Average yield of two years' study in SP cultivar per plant was $45 \mathrm{~kg}$ to $62 \mathrm{~kg}$ ( Figure 4). On the other hand, YP cultivar gives fruits three times per year which has been mentioned in the Table 2 , and its total production per plant was $28-38 \mathrm{~kg}$. This yield is consistence with the biomass production performance like the fruit length and seed numbers per pod in different cultivars ( Table 1). Production was statistically significantly different between the two cultivars but identical production in the same cultivar of two locations. It indicates that ecological different did not give any significant difference in the same cultivar. Because, both areas meteorological condition is nearly similar ( Figures 1 and 2 ). Although, a bit higher yield was found in the second-year study (2017) but there are no significant variations were found in the same cultivar of same location between the two years' study. Ndubuaku et al. ${ }^{(39)}$ recorded the three years yield continuously, and they did not get the significant variations of pod yield. Overall, higher amount of production in SP has shown the coherent reasons: because fruit length, number of seeds per pod including the number of secondary leaves is higher compared to YP.

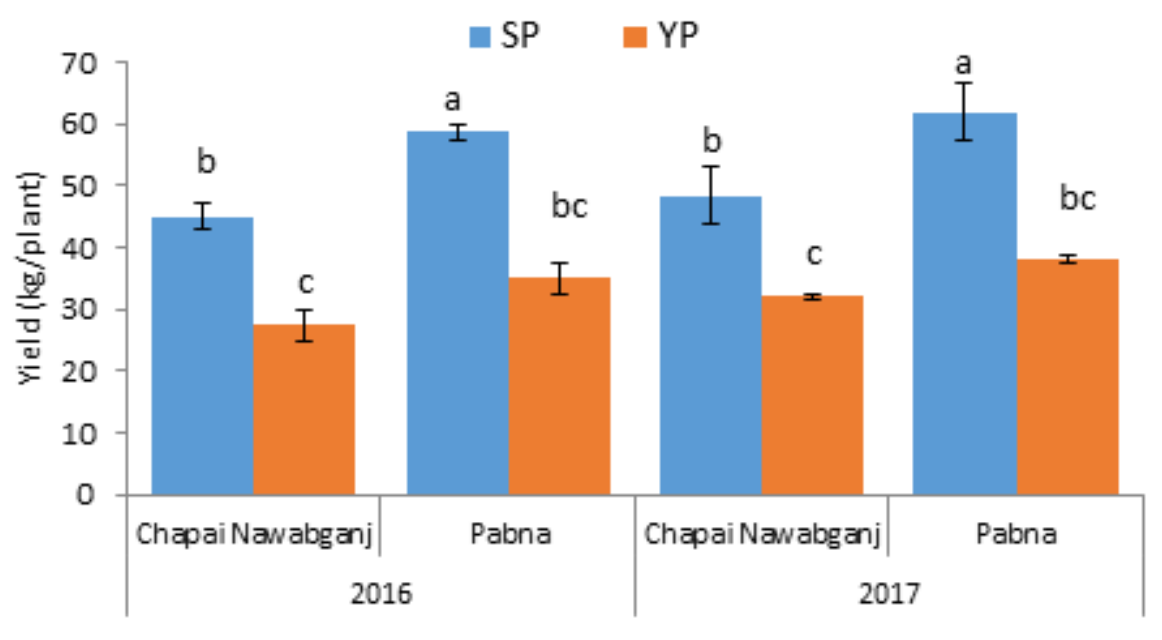

Fig 4. Yield of two varieties moringa under two ecological conditions in Bangladesh for the year 2016 and 2017.

Vertical bars represent the \pm SE (standard error). Mean values with the same letters are not significantly different based on ANOVA followed by a Tukey's test at $\mathrm{p} \leq 0.05$.

Perception of people have been observed that year-round cultivars are found demanding. Because this cultivar gives flowers three times per year e.g. last week of February to March, June to July and September to October whereas the harvesting time of fruit is generally, mid-April to May, August to September and November to December, respectively ( Table 2 ). Ultimately, it avails the fruit all the year round except January and February, and palatability taste of this cultivar is better than the seasonal cultivars (personal communication). Other reasons are providing economical support during the off-season and nutrition to the small household family members for the year round. On the other hand, seasonal cultivar gives flower in the month of last week of January to March and fruit comes during mid-March to April.

Average moisture content of leaves in both cultivars of two ecological zones ranged from 68 to $74 \%$, whereas no significant variations were found. ( Table 3). The lowest moisture content of leaves $(68.82 \%)$ was found in SP grown under Chapai Nawabganj $\left(\mathrm{L}_{1}\right)$ and the highest amount moisture $(73.60 \%)$ content was found in the same cultivar grown in the Pabna district $\left(\mathrm{L}_{2}\right)$. Similarly, dry matter content in both cultivars of two locations were identical. Even though, the lowest dry matter $(26.4 \%)$ content was found in SP of the Pabna district $\left(\mathrm{L}_{2}\right)$ and the highest dry matter $(31.18 \%)$ content was found in SP of the area Chapai Nawabganj $\left(\mathrm{L}_{1}\right)$. 


\subsection{Protein and other nutrients content in moringa leaves and pod}

Protein content in leaves and pods were significantly different. Leaves contained over two-times the amount of protein as the pods. Leaves contain an average protein content of $29-33 \%$ while pods had an average of $13 \%$. This finding is similar to previously reported by Sanchez-Machado et al. ${ }^{(31)}$. Jongrungruangchok et al. ${ }^{(40)}$ studied the protein content in leaves from 11 agro-ecological zones in Thailand and found a range of 19 to $29 \%$ protein. Olson et al. ${ }^{(41)}$ also conducted protein on the different taxa of moringa. They have got the highest amount of protein in M. oleifera compared to others species but the average value of protein $(29.1 \%)$ found with wide variation and could not identify the reasons of variation. On the other hand, we know the pulse contain higher amount protein; and Sotelo and Adsule ${ }^{(42)}$ reported that Chickpea, lentil, and dry pea contain approximately $22 \%, 28.6 \%$, and $23.3 \%$ protein which is not higher amount of protein compared to moringa leaves and pods protein content.

Calcium (Ca) levels were found in the leaves to be 2313 to $3487 \mathrm{ppm}$, and 2017 to $2032 \mathrm{ppm}$ in the pods ( Table 4 ). Considering human nutrition, milk is the good source of calcium to prevent osteoporosis. Soyeurt et al. ${ }^{(43)}$ analysed the cow milk directly which was 1021 to $1087 \mathrm{ppm}$. It indicates that moringa leaves and pods contain minimum 2 to 3 times higher calcium compared to the cow milk. Leaves contain more than 4 times higher amounts of Fe compared to pods. Leaves of SP and YP contain 277 and 419 ppm, respectively whereas pods of SP and YP contain 68 and 61 ppm, respectively ( Figure 5 ). It can be mentioned that $\mathrm{Ca}$ and $\mathrm{Fe}$ is very important elements for the human body and maintain the teeth and bones formation. This mineral has contribution to normal blood clotting and nervous function as well. Fe helps in oxygen transport in the human body through binding the oxygen to haemoglobin and myoglobin; and allow electrons in the electron transport chain for the formation of $\mathrm{ATP}^{(44)}$. Hels et al. ${ }^{(45)}$ conducted an experiment to analysis the different minerals and vitamin content of commonly used 15 vegetables in Bangladesh. They found the higher amount of $\mathrm{Ca}$ and Fe in amaranth leaves 26 and $430 \mathrm{ppm}$, respectively. Comparing the $\mathrm{Ca}$ and Fe content both in pods of leaves of moringa contain 78 to 134 times higher $\mathrm{Ca}$ than other leafy vegetables indication is the consumption of moringa leaves or pods can ensure the nutrition security which can reduce the risk of cancer ${ }^{(46)}$.

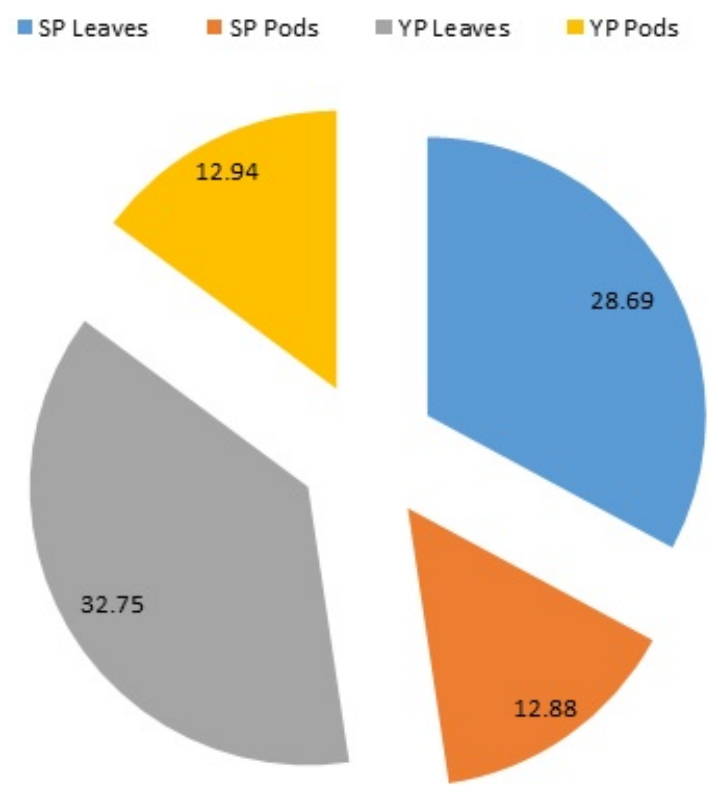

Fig 5. Contents of protein in different edible parts of moringa of two varieties of moringa. Here, SP: Seasonal production, YP: Year -round production cultivar.

It was found $\mathrm{P}$ content was significantly higher in pods (1.46 to $1.68 \%)$ compared to leaves $(0.34$ to $0.38 \%)$. These results support the study of Moyo et al. ${ }^{(20)}$ where P content in leaves of African ecotype Moringa was near to similar percentage of this study. Phosphorous is also an essential element to function the physiological and chemical process for all living organism and cannot be replaced by any other elements ${ }^{(47)}$. Potassium content in the leaves and pods was found to be very similar $(3.17$ to $3.29 \%$ ) ( Table 4). Moyo et al. ${ }^{(20)}$ analyzed the K content in moringa leaves in South Africa and reported the content of $\mathrm{K}$ 
(1.50\%) which is lower compared to the Bangladeshi cultivars. $\mathrm{Na}$ and $\mathrm{Mg}$ contents were found higher in pods whereas low amount in leaves ( Figure 6 Table 4). Mg content in leaves were abruptly lower. 4). Although, Moyo et al. ${ }^{(20)}$ found the higher amounts of $\mathrm{Na}$ and $\mathrm{Mg}$ in leaves of moringa compared to the Bangladeshi moringa cultivars.

Variations of protein and micronutrients in different parts of moringa and similar parts from different regions has been previously reported ${ }^{(48)}$. Jongrungruangchok et al. ${ }^{(40)}$ reported wide variations in nutrient such as potassium, Ca, Mg, Fe across moringa grown in different ecological zones. Variation in the nutritional values in plant species differ for a wide range of reasons, such as cultivation regions, growing conditions, nature of soil, seasonal changes, genetically difference and storage conditions. Overall, variation among the nutritional values of moringa varieties can be attributed to genetic, environmental and cultivation factors; and it is one of the most prominent industrial crops considering the nutritional and nutraceutical values ${ }^{(49,50)}$. Besides, it has been documented that moringa consumers are found food and nutritionally secured; and food fortification through moringa leaves powder is another way to improve the nutritional security status ${ }^{(51,52)}$.

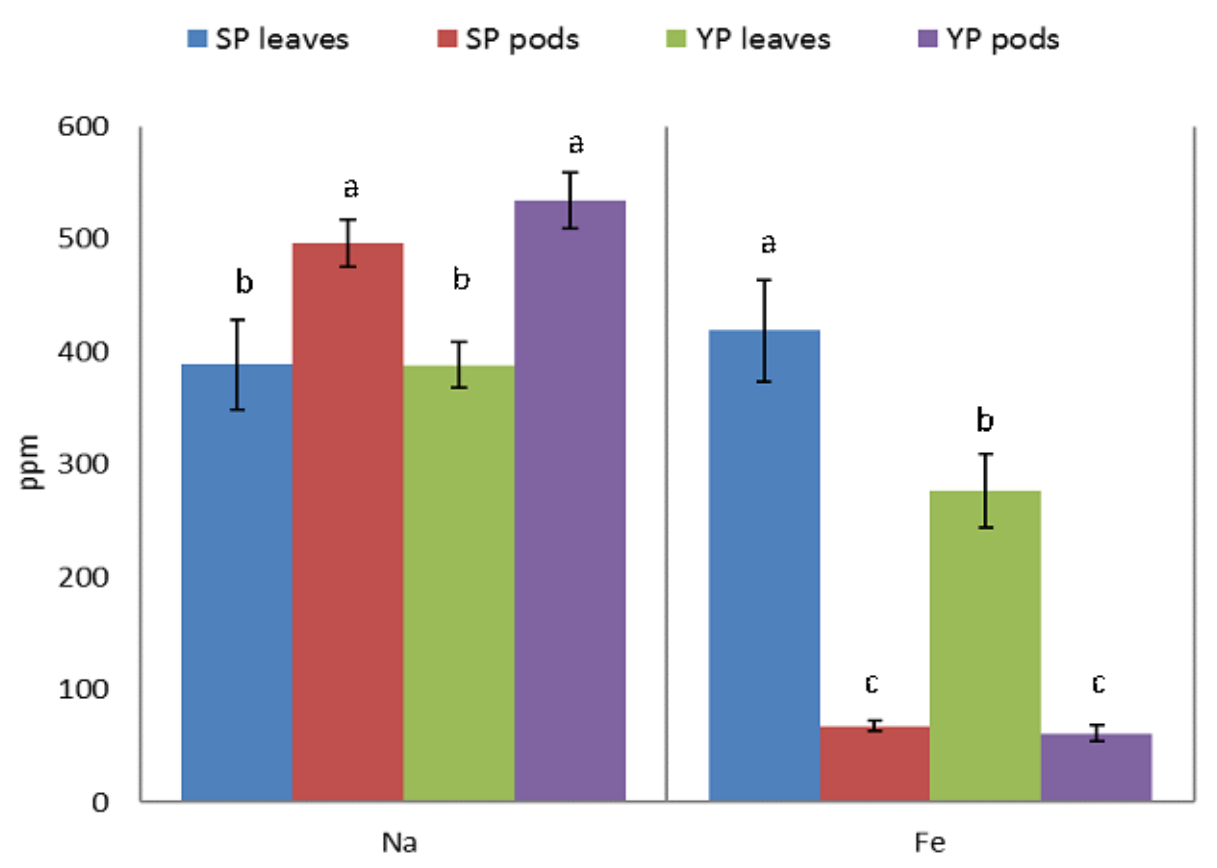

Fig 6. Sodium and iron contents (ppm) in different edible parts of two cultivars moringa.

Here, SP: seasonal production cultivar and YP:Year-round production cultivar. Vertical bars represent the \pm SE (standard error). Mean values with the same letters are not significantly different based on ANOVA followed by a Tukey's test at $\mathrm{p} \leq 0.05$.

Table 4. Mineral contents in the edible parts of two moringa cultivars

\begin{tabular}{llllll}
\hline Cultivar & Plant parts & $\mathrm{P}(\%)$ & $\mathrm{K}(\%)$ & $\mathrm{Ca}(\mathrm{ppm})$ & $\mathrm{Mg}(\mathrm{ppm})$ \\
\hline \multirow{2}{*}{$\mathrm{SP}$} & Leaves & $0.34 \pm 0.04 \mathrm{~b}$ & $3.25 \pm 0.233 \mathrm{a}$ & $3487.28 \pm 412.0 \mathrm{a}$ & $90.86 \pm 3.58 \mathrm{~b}$ \\
& Pods & $1.46 \pm 0.15 \mathrm{a}$ & $3.17 \pm 0.33 \mathrm{a}$ & $2016.54 \pm 53.6 \mathrm{~b}$ & $1768.28 \pm 159 \mathrm{a}$ \\
\hline \multirow{2}{*}{$\mathrm{YP}$} & Leaves & $0.38 \pm 0.03 \mathrm{~b}$ & $3.20 \pm 0.20 \mathrm{a}$ & $2313.57 \pm 141.0 \mathrm{~b}$ & $55.81 \pm 5.82 \mathrm{~b}$ \\
& Pods & $1.68 \pm 0.20 \mathrm{a}$ & $3.29 \pm 0.18 \mathrm{a}$ & $2032.32 \pm 54.3 \mathrm{~b}$ & $1861.56 \pm 104.0 \mathrm{a}$ \\
\hline
\end{tabular}

Mean \pm SE (standard error) followed by non-similar letters are significantly different at $\mathrm{p} \leq 0.05$ according to Tukey's test. Here, SP: seasonal production cultivar and YP: Year-round production cultivar.

\section{Conclusions}

This study demonstrates the importance of moringa leaves and pods as a food source with high nutritional density. The leaves were found to be a better source of protein, $\mathrm{Ca}$ and $\mathrm{Fe}$; while the pods were higher in $\mathrm{P}, \mathrm{Na}$ and $\mathrm{Mg}$. It indicates that both edible 
parts (leaves and pods) and especially leaves have the potential to be used as micronutrient supplements for food products. Although, some parts of Bangladeshi people consume both parts (leaves and pods) as vegetables and some parts are used to consume only pods. To some extent, leaves can be used for fortification to different confectionery product and also can be processed as feed as well. There is a gap to create awareness among those which areas people are consuming only pods. Overall, these findings might be a reference point in Bangladesh for the cultivar selection and formulation of moringa-based food supplement in human nutrition.

\section{Acknowledgments}

The research was supported by the Bangladesh Agricultural University and University Grants Commission. The authors would like to thank to the moringa farmers for their kind help to conduct this study.

\section{Disclosure statement}

There is no conflict of interest.

\section{References}

1) Palada MC. Moringa (Moringa oleifera Lam.): A versatile tree crop with horticultural potential in the subtropical United States. HortScience. 1996; 31(5):794-797. Available from: https://dx.doi.org/10.21273/hortsci.31.5.794.

2) Palada MC, Chang LC. Suggested cultural practices for moringa. In: and others, editor. AVRDC International Cooperators' Guide. 2003. Available from: http://www.avrdc.org/LC/indigenous/moringa.pdf.

3) Fuglie LJ. The Miracle Tree: Moringa oleifera: Natural Nutrition for the Tropics. Church World Service. 1999.

4) Emongor VE. Proc. First All African Horticultural Congress, Acta Hort. Wesonga J, Kahane R, editors. 2011.

5) Anwar F, Latif S, Ashraf M, Gilani AH. Moringa oleifera: a food plant with multiple medicinal uses. Phytotherapy Research. 2007;21(1):17-25. Available from: https://dx.doi.org/10.1002/ptr.2023.

6) Fahey J. Moringa oleifera: A review of the medical evidence for its nutritional therapeutic, and prophylactic properties. Part 1. Trees for Life Journal. 2005.

7) Thurber DM, Fahey WJ. Adoption of Moringa oleiferato Combat Under-Nutrition Viewed Through the Lens of the "Diffusion of Innovations" Theory. Ecology of Food and Nutrition. 2009; 48(3):212-225. Available from: https://dx.doi.org/10.1080/03670240902794598.

8) Dhakad KA, Ikram M, Sharma S, Khan S, Pandey VV, Singh A. Biological, nutritional, and therapeutic significance of Moringa oleifera Lam. Phytotherapy Research. 2019;33(11):2870-2903. Available from: https://dx.doi.org/10.1002/ptr.6475.

9) Chukwuebuka E. Moringa oleifera "The Mother's Best Friend". International Journal of Nutrition and Food Sciences. 2015; 4(6):624-630. Available from: https://doi.org/10.11648/j.ijnfs.20150406.14.

10) Oyeyinka TA, Oyeyinka AS. Moringa oleifera as a food fortificant: Recent trends and prospects. Journal of the Saudi Society of Agricultural Sciences. 2018; 17(2):127-136. Available from: https://dx.doi.org/10.1016/j.jssas.2016.02.002.

11) Makkar HPS, Becker K. Nutrients and antiquality factors in different morphological parts of the Moringa oleifera tree. The Journal of Agricultural Science. 1997; 128(3):311-322. Available from: https://dx.doi.org/10.1017/s0021859697004292.

12) Chuang P, Lee C, Chou JY, Murugan M, Sheih B, Chen H. Anti-fungal activity of crude extracts and essential oil of Moringa oleifera Lam. Bioresource Technology. 2007; 98(1):232-236. Available from: https://dx.doi.org/10.1016/j.biortech.2005.11.003.

13) Sánchez NR, Spörndly E, Ledin I. Effect of feeding different levels of foliage of Moringa oleifera to creole dairy cows on intake, digestibility, milk production and composition. Livestock Science. 2006;101(1-3):24-31. Available from: https://dx.doi.org/10.1016/j.livprodsci.2005.09.010.

14) Richter N, Siddhuraju P, Becker K. Evaluation of nutritional quality of moringa (Moringa oleifera Lam.) leaves as an alternative protein source for Nile tilapia (Oreochromis niloticus L.). Aquaculture. 2003;217(1-4):599-611. Available from: https://dx.doi.org/10.1016/s0044-8486(02)00497-0.

15) Ndemanisho EE, Kimoro BN, Mtengeti EJ, Muhikambele VRM. The potential of Albizia lebbeck as a supplementary feed for goats in Tanzania. Agroforestry Systems. 2006;67(1):85-91. Available from: https://dx.doi.org/10.1007/s10457-005-2648-1.

16) Rashid U, Anwar F, Moser BR, Knothe G. Moringa oleifera oil: A possible source of biodiesel. Bioresource Technology. 2008;99(17):8175-8179. Available from: https://dx.doi.org/10.1016/j.biortech.2008.03.066.

17) Salem HB, Makkar HPS. Defatted Moringa oleifera seed meal as a feed additive for sheep. Animal Feed Science and Technology. 2009;150(1-2):27-33. Available from: https://dx.doi.org/10.1016/j.anifeedsci.2008.07.007.

18) Kwaambwa HM, Maikokera R. A fluorescence spectroscopic study of a coagulating protein extracted from Moringa oleifera seeds. Colloids and Surfaces B: Biointerfaces. 2007;60(2):213-220. Available from: https://dx.doi.org/10.1016/j.colsurfb.2007.06.015.

19) Hsu R, Midcap S, Arbainsyah I, Witte DL. Moringa oleifera; Medicinal and socioeconomic uses. International Course on Economic Botany. National Herbarium Leiden, The Netherlands. 2006.

20) Busani M, Patrick JM, Arnold H, Voster M. Nutritional characterization of Moringa (Moringa oleifera Lam.) leaves. African Journal of Biotechnology. 2011;10(60):12925-12933. Available from: https://dx.doi.org/10.5897/ajb10.1599.

21) Anwar F, Rashid U. Physico-chemical characteristics of Moringa oleifera seeds and seed oil from a wild provenance of Pakistan. Pakistan Journal of Botany. 2007;39:1443-1453.

22) Falowo BA, Mukumbo EF, Idamokoro ME, Lorenzo MJ, Afolayan JA, Muchenje V. Multi-functional application of Moringa oleifera Lam. in nutrition and animal food products: A review. Food Research International. 2018;106:317-334. Available from: https://dx.doi.org/10.1016/j.foodres.2017.12.079.

23) Pullakhandam R, Failla LM. Micellarization and Intestinal Cell Uptake of $\beta$-Carotene and Lutein from Drumstick (Moringa oleifera) Leaves. Journal of Medicinal Food. 2007;10(2):252-257. Available from: https://dx.doi.org/10.1089/jmf.2006.250.

24) Siddhuraju P, Becker K. Antioxidant properties of various solvent extracts of total phenolic constituents from three different agroclimatic origins of Drumstick tree (Moringa oleifera Lam.) leaves. Journal of Agricultural and Food Chemistry. 2003;51(8):2144-2155. Available from: https://dx.doi.org/10. $1021 /$ jf020444+. 
25) Waterman C, Cheng MD, Rojas-Silva P, Poulev A, Dreifus J, Lila MA, et al. Stable, water extractable isothiocyanates from Moringa oleifera leaves attenuate inflammation in vitro. Phytochemistry. 2014;103:114-122. Available from: https://dx.doi.org/10.1016/j.phytochem.2014.03.028.

26) Oduro I, Ellis WO, Owusu D. Nutritional Potential of two leafy vegetables: Moringa oleifera and Ipomoea batatas leaves. Scientific Research and Essays. 2008;3(2):57-60.

27) Abraham SI, Gernah DI, Abu JO. Effect of Moringa oleifera leaf powder supplementation on some quality characteristics of wheat bread. Food and Nutrition Sciences. 2013;4:270-275. Available from: https://doi.org/10.4236/fns.2013.43036.

28) Serafico ME, Perlas LA, Magsadia CR, Desnacido JA, Viajar RV, Rongavilla EO, et al. Efficacy of Malunggay (Moringa oleifera) leaves in improving the iron and vitamins A and B status of Filipino school children. In: and others, editor. International Symposium on Moringa. 1158;p. 293-302. Available from: https://doi.org/10.17660/ActaHortic.2017.1158.33.

29) Sena LP, Vander-Jagt DJ, Rivera C, Tsin A, Muhamadu I, Mahammaduo O, et al. Analysis of nutritional components of eight famine foods of the republic of Nigeria. Plant Foods for Human Nutrition. 1998;52(1):17-30. Available from: https://doi.org/10.1023/a:1008010009170.

30) Freiberger C, Vanderjagt D, Pastuszyn A, Glew R, Mounkaila G, Millson M, et al. Nutrient content of the edible leaves of seven wild plants from Niger. Plant Foods for Human Nutrition. 1998;53:57-69. Available from: https://doi.org/10.1023/A:1008080508028.

31) Sánchez-Machado DI, Núñez-Gastélum JA, Reyes-Moreno C, Ramírez-Wong B, López-Cervantes J. Nutritional Quality of Edible Parts of Moringa oleifera. Food Analytical Methods. 2010;3(3):175-180. Available from: https://dx.doi.org/10.1007/s12161-009-9106-z.

32) Bremner JM, Mulvaney CS. Nitrogen -total. In: AL P, RH M, , DR K, editors. Methods of soil analysis. Part;vol. 2. American Society of Agronomy, Inc. and Soil Science Society America, Inc. 1982;p. 595-622.

33) Singh P, Garg AK, Malik R, Agrawal DK. Effect of replacing barley grain with wheat bran on intake and utilisation of nutrients in adult sheep. Small Ruminant Research. 1999;31(3):215-219. Available from: https://dx.doi.org/10.1016/s0921-4488(98)00145-x.

34) Baker DE, Suhr NH. Atomic absorption and flame emission spectrometry. In: AL P, RH M, , DR K, editors. Methods of soil analysis. Part; vol. 2. American Society of Agronomy, Inc. and Soil Science Society America, Inc. 1982;p. 13-26.

35) Olsen SR, Sommers LE. Phosphorous. In: Methods of soil analysis. Part 2. vol. 2. Madison, Wisconsin, USA. American Society of Agronomy, Inc. and Soil Science Society America, Inc. 1982;p. 403-427.

36) Knudsen D, Peterson GA, Prat PF. Lithium, sodium and potassium. In: Page AL, Miller RH, Keeney DR, editors. Methods of soil analysis. Part;vol. 2. American Society of Agronomy, Inc. and Soil Science Society America, Inc. 1982;p. 225-246.

37) Osman HE, Abohassan AA. Morphological and Analytical characterization of Moringa peregrina populations In Western Saudi Arabia. International Journal of Theoretical and Applied Sciences. 2012;4(2):174-184.

38) Stevens CG, Ugese FD, Baiyeri KP. Effect of pig manure on growth and productivity of twenty accessions of Moringa oleifera in Nigeria. Agro-Science. 2019;17(3):19-19. Available from: https://dx.doi.org/10.4314/as.v17i3.4.

39) Ndubuaku UM, Ndubuaku TCN, Ndubuaku NE. Yield characteristics of Moringa oleifera across different ecologies in Nigeria as an index of its adaptation to climate change. Sustainable Agriculture Research. 2014;3(1). Available from: https://dx.doi.org/10.5539/sar.v3n1p95.

40) Jongrungruangchok S, Bunrathep S, Songsak T. Nutrients and minerals content of eleven different samples of Moringa oleifera cultivated in Thailand. Journal of Health Research. 2010;24(3):123-127.

41) Olson EM, Sankaran PR, Fahey WJ, Grusak AM, Odee D, Nouman W. Leaf protein and mineral concentrations across the "miracle tree" genus Moringa. PLOS ONE. 2016;11(7). Available from: https://dx.doi.org/10.1371/journal.pone.0159782.

42) Sotelo A, Adsule RN. Food and feed from legumes and oilseeds. Chapman and Hall. 2012;p. 82-89.

43) Soyeurt H, Bruwier D, Romnee JM, Gengler N, Bertozzi C, Veselko D, et al. Potential estimation of major mineral contents in cow milk using mid-infrared spectrometry. Journal of Dairy Science. 2009;92(6):2444-2454. Available from: https://dx.doi.org/10.3168/jds.2008-1734.

44) Kozat S. Serum T3 and T4 concentrations in lambs with nutritional myodegeneration. Journal of Veterinary Internal Medicine. 2007;21:1135-1137.

45) Hels O, Larsen T, Christensen PL, Kidmose U, Hassan N, Thilsted SH. Contents of iron, calcium, zinc and $\beta$-carotene in commonly consumed vegetables in Bangladesh. Journal of Food Composition and Analysis. 2004; 17(5):587-595. Available from: https://dx.doi.org/10.1016/j.jfca.2003.08.007.

46) Lappe JM, Travers-Gustafson D, Davies KM, Recker RR, Heaney RP. Vitamin D and calcium supplementation reduces cancer risk: results of a randomized trial. The American Journal of Clinical Nutrition. 2007;85(6):1586-1591. Available from: https://dx.doi.org/10.1093/ajcn/85.6.1586.

47) Taddese G. The Future Challenge of Phosphorous in Africa. Journal of Agriculture and Forest Meteorology Research. 2019;2(4):143-156.

48) Anjorin TS, Ikokoh P, Okol S. Mineral composition of Moringa oleifera leaves. International Journal of Agriculture and Biology. 2010;12:431-434.

49) Brisibe EA, Umoren EU, Brisibe F, Magalhäes PM, Ferreira FSJ, Luthria D, et al. Nutritional characterisation and antioxidant capacity of different tissues of Artemisia annua L. Elsevier BV. 2009. Available from: https://dx.doi.org/10.1016/j.foodchem.2009.01.033. doi:10.1016/j.foodchem.2009.01.033.

50) Saini RK, Sivanesan I, Keum YS. Phytochemicals of Moringa oleifera: a review of their nutritional, therapeutic and industrial significance. 3 Biotech. 2016;6:203-216. Available from: https://dx.doi.org/10.1007/s13205-016-0526-3.

51) Tafesse A, Goshu D, Gelaw F, Ademe A. Food and nutrition security impacts of Moringa: Evidence from Southern Ethiopia, Cogent Food and Agriculture. 2020. Available from: https://doi.org/10.1080/23311932.2020.1733330.

52) Zungu N, van Onselen A, Kolanisi U, Siwela M. Assessing the nutritional composition and consumer acceptability of Moringa oleifera leaf powder (MOLP)-based snacks for improving food and nutrition security of children. South African Journal of Botany. 2020;129:283-290. Available from: https://dx.doi.org/10.1016/j.sajb.2019.07.048. 